\title{
Expression of the Escherichia coli pntAB genes encoding a membrane-bound transhydrogenase in Corynebacterium glutamicum improves L-lysine formation
}

\author{
Armin Kabus • Tobias Georgi • Volker F. Wendisch • \\ Michael Bott
}

Received: 6 November 2006 /Revised: 7 December 2006 / Accepted: 8 December 2006 / Published online: 11 January 2007

(C) Springer-Verlag 2007

\begin{abstract}
A critical factor in the biotechnological production of L-lysine with Corynebacterium glutamicum is the sufficient supply of NADPH. The membrane-integral nicotinamide nucleotide transhydrogenase PntAB of Escherichia coli can use the electrochemical proton gradient across the cytoplasmic membrane to drive the reduction of $\mathrm{NADP}^{+}$ via the oxidation of NADH. As C. glutamicum does not possess such an enzyme, we expressed the $E$. coli pntAB genes in the genetically defined $C$. glutamicum lysineproducing strain DM1730, resulting in membrane-associated transhydrogenase activity of $0.7 \mathrm{U} / \mathrm{mg}$ protein. When cultivated in minimal medium with $10 \%(w / v)$ carbon source, the presence of transhydrogenase slightly reduced glucose consumption, whereas the consumption of fructose, glucose plus fructose, and, in particular, sucrose was stimulated. Biomass was increased by pntAB expression between 10 and $30 \%$ on all carbon sources tested. Most importantly, the lysine concentration was increased in the presence of transhydrogenase by $\sim 10 \%$ on glucose, $\sim 70 \%$ on fructose, $\sim 50 \%$ on glucose plus fructose, and even by $\sim 300 \%$ on sucrose. Thus, the presence of a proton-coupled transhydrogenase was shown to be an efficient way to improve lysine production by $C$. glutamicum. In contrast, pntAB expression had a negative effect on growth and glutamate production of $C$. glutamicum wild type.
\end{abstract}

\footnotetext{
A. Kabus $\cdot$ T. Georgi $\cdot$ M. Bott $(\bowtie)$

Institut für Biotechnologie 1,

Forschungszentrum Jülich,

52425 Jülich, Germany

e-mail: m.bott@fz-juelich.de

V. F. Wendisch

Institut für Molekulare Mikrobiologie und Biotechnologie,

Westfälische Wilhelms-Universität,

Münster, Germany
}

Keywords Corynebacterium glutamicum - Escherichia coli . Lysine production - Glutamate production - Glucose . Fructose $\cdot$ Sucrose $\cdot$ Nicotinamide nucleotide transhydrogenase $\cdot$ pnt $A B$

\section{Introduction}

The Gram-positive aerobic soil bacterium Corynebacterium glutamicum is of major importance in the industrial production of amino acids, in particular, L-glutamate (Kimura 2005) and L-lysine (Hermann 2003; Kelle et al. 2005). A number of molecular targets essential for efficient lysine production have been identified in the lysine biosynthesis pathway, in pathways competing with lysine formation for common intermediates and in pathways providing the precursor oxaloacetate (Eggeling 1994; Hermann 2003; Pfefferle et al. 2003; Sahm et al. 2000). Based on that knowledge, introduction of favorable point mutations in the aspartokinase gene lys $C$, in the homoserine dehydrogenase gene hom and in the pyruvate carboxylase gene $p y c$, which had been uncovered in a classically obtained lysine producer, into the $C$. glutamicum wild-type genome resulted in a very efficient lysine production strain (Ohnishi et al. 2002).

In C. glutamicum, lysine biosynthesis involves a split pathway in which L,L-diaminopimelate is formed from tetrahydrodipicolinate either via the energetically less expensive diaminopimelate dehydrogenase when ammonium is in excess or via the energetically more costly tetrahydrodipicolinate succinylase pathway when the ammonium concentration is low (Eggeling and Sahm 1999). Both pathways require $4 \mathrm{~mol}$ NADPH per mol lysine starting from oxaloacetate. In principle, NADPH can be synthesized in C. glutamicum by the enzymes of the 
oxidative pentose phosphate pathway (PPP), glucose-6phosphate dehydrogenase and 6-phosphogluconate dehydrogenase (Moritz et al. 2000), by isocitrate dehydrogenase (Eikmanns et al. 1995) and by malic enzyme (Gourdon et al. 2000). Carbon flux analysis revealed that during growth on glucose, NADPH for lysine biosynthesis is provided by the PPP, whereas isocitrate dehydrogenase and malic enzyme are of minor importance (Marx et al. 1996, 1997, 1999, 2003). During growth of C. glutamicum on fructose or on fructose/glucose mixtures, a low carbon flux through the oxidative PPP was demonstrated (Dominguez et al. 1998; Kiefer et al. 2004; Pons et al. 1996). It was proposed that to meet the NADPH requirement for growth and lysine production on fructose or on fructose/glucose mixtures, malic enzyme activity has to be increased (Dominguez et al. 1998). As fructose is transported into the cell as fructose-1-phosphate by a PEP-dependent phosphotransferase system and enters glycolysis after phosphorylation to fructose-1,6-bisphosphate (Kotrba et al. 2001; Parche et al. 2001), overexpression of the fructose-1,6-bisphosphatase gene $f b p$ (Rittmann et al. 2003) was alternatively proposed to increase the PPP flux as well as lysine production on fructose (Kiefer et al. 2004; Pons et al. 1996). We could recently show that overexpression of the malE gene encoding malic enzyme in the genetically defined C. glutamicum strain DM1730 has no positive effect on lysine production on glucose, fructose, glucose/fructose, or sucrose (Georgi et al. 2005). Whereas overexpression of $f b p$ in this strain did not effect lysine production on glucose, fructose, or a glucose/fructose mixture, the lysine yield on sucrose was increased twofold (Georgi et al. 2005).

Escherichia coli and a variety of other bacteria, but not C. glutamicum, possess a membrane-bound nicotinamide nucleotide transhydrogenase encoded by the pntAB genes which uses the electrochemical proton gradient as driving force for the reduction of $\mathrm{NADP}^{+}$to NADPH by oxidation of NADH to $\mathrm{NAD}^{+}$according to the following equation: $\mathrm{NADH}+\mathrm{NADP}^{+}+\mathrm{H}_{\text {out }}^{+} \rightarrow \mathrm{NAD}^{+}+$ $\mathrm{NADPH}+\mathrm{H}_{\text {in }}^{+}$(Jackson 2003). The E. coli transhydrogenase PntAB is composed of two membrane-spanning subunits, $\alpha(50 \mathrm{kDa})$ and $\beta(47 \mathrm{kDa})$, arranged as an $\alpha_{2} \beta_{2}$ heterotetramer (Clarke and Bragg 1985; for review, see Jackson 2003). Sauer et al. (2004) reported that during aerobic batch cultivation of $E$. coli in minimal medium, glucose catabolism alone generated less NADPH than was required for biosynthesis and that the membrane-bound transhydrogenase contributed $35-45 \%$ of the total anabolic demand for NADPH under these conditions, although it was not essential for growth on glucose.

In this paper, we report on the expression of the E. coli pntAB genes in C. glutamicum. Our objective was to determine if a membrane-bound transhydrogenase could serve as an alternative source of NADPH. In contrast to the oxidative PPP, transhydrogenase activity is not accompanied by a loss of substrate carbon as carbon dioxide and, thus, might allow for increased lysine yields.

\section{Materials and methods}

Bacterial strains and culture conditions

The C. glutamicum strains and plasmids used in this work are listed in Table 1. For analysing lysine or glutamate production, a brain-heart infusion preculture was inoculated from a fresh Luria-Bertani (LB) plate and cultivated overnight. After washing cells in CGXII medium (as described by Keilhauer et al. 1993, but with $30 \mathrm{mg} / 1$ 3,4dihydroxybenzoic acid as iron chelator) without carbon source, the main culture with CGXII medium was inoculated to an $\mathrm{OD}_{600}$ of 1 . For lysine production, $10 \%$ $(w / v)$ glucose, $10 \%(w / v)$ fructose, $10 \%(w / v)$ sucrose, or $5 \%(w / v)$ glucose plus $5 \%(w / v)$ fructose were used as carbon source, whereas for glutamate production, $4 \%(w / v)$ glucose, $4 \%(w / v)$ fructose, $4 \%(w / v)$ sucrose or $2 \%(w / v)$ glucose $+2 \%(w / v)$ fructose were used. To trigger glutamate production, $300 \mu \mathrm{g} / \mathrm{ml}$ ethambutol was added to the minimal medium (Radmacher et al. 2005). After $72 \mathrm{~h}$ in the case of lysine production or after $27 \mathrm{~h}$ in the case of glutamate production, samples were withdrawn from the cultures for the determination of the amino acid and sugar concentrations in the medium. C. glutamicum cultivations were performed in baffled 500-ml Erlenmeyer flasks with $60 \mathrm{ml}$ medium at $30^{\circ} \mathrm{C}$ and $120 \mathrm{rpm}$. E. coli DH $5 \alpha$, which was used as host for cloning, was cultivated in LB medium or on LB agar plates at $37^{\circ} \mathrm{C}$. When appropriate, kanamycin was used at a concentration of 25 $50 \mu \mathrm{g} / \mathrm{ml}$ and isopropyl $\beta$-D-1-thiogalactopyranoside (IPTG) at a concentration of $1 \mathrm{mM}$.

Preparation of DNA and transformation

Chromosomal DNA from E. coli was isolated as described by Ausubel et al. (1992). Plasmid DNA was isolated with the QIAprep spin miniprep kit (Qiagen, Hilden, Germany). Transformation of $E$. coli was performed using the rubidium chloride method (Hanahan 1985), whereas $C$. glutamicum was transformed by electroporation as described by van der Rest et al. (1999).

Construction of a pntAB expression plasmid

For pntAB overexpression in C. glutamicum, the genes were cloned into the vector pEKEx2 (Eikmanns et al. 1991) under the control of an IPTG-inducible tac promoter. 
Table 1 Strains and plasmids used in this study

\begin{tabular}{|c|c|c|}
\hline $\begin{array}{l}\text { Strain or } \\
\text { plasmid }\end{array}$ & Relevant characteristics & Reference/source \\
\hline \multicolumn{3}{|l|}{ Strains } \\
\hline $\begin{array}{l}\text { C. glutamicum } \\
\text { ATCC13032 }\end{array}$ & Wild-type, biotin-auxotrophic & Abe et al. (1967) \\
\hline $\begin{array}{l}\text { C. glutamicum } \\
\text { DM1730 }\end{array}$ & $\begin{array}{l}\text { pyc } c^{\mathrm{P} 458 \mathrm{~S}} ; h_{o m}{ }^{\mathrm{V} 59 \mathrm{~A}} ; l y s^{\mathrm{CT} 311 \mathrm{I}} ; z w f^{\mathrm{A} 243 \mathrm{~T}} \text { derived from } \\
\text { ATCC } 13032\end{array}$ & B. Bathe; Degussa AG \\
\hline E. coli $\mathrm{DH} 5 \alpha$ & $\begin{array}{l}\mathrm{F}^{-} \Phi 80 \text { dlac } \Delta(\text { lacZ)M15 } \Delta(\text { lacZYA-argF }) \mathrm{U} 169 \text { endA1 } \\
\text { recAl hsdR17 }\left(\mathrm{r}_{\mathrm{K}}^{-}, \mathrm{m}_{\mathrm{K}}^{+}\right) \text {deoR thi-1 phoA } \\
\quad \text { supE44 } \lambda^{-} \text {gyrA96 relA1 }\end{array}$ & $\begin{array}{l}\text { Invitrogen } \\
\text { (Karlsruhe, Germany) }\end{array}$ \\
\hline \multicolumn{3}{|l|}{ Plasmids } \\
\hline pEKEx2 & $\begin{array}{l}\mathrm{Kan}^{\mathrm{R}} ; \text { E. coli-C. glutamicum shuttle vector for regulated } \\
\text { gene expression }\left(\mathrm{P}_{t a c}, \text { lacl }^{\mathrm{q}}, \mathrm{pBL} 1 \text { ori }_{C g}, \mathrm{pUC} 18 \text { ori } V_{E_{c}}\right)\end{array}$ & Eikmanns et al. (1991) \\
\hline $\begin{array}{l}\text { pEKEx2- } \\
\text { pntAB }\end{array}$ & $\begin{array}{l}\mathrm{Kan}^{\mathrm{R}} \text {; pEKEx } 2 \text { derivative containing the E. coli pntAB genes } \\
\text { under the control of an IPTG-inducible tac promoter }\end{array}$ & This work \\
\hline
\end{tabular}

To this end, the $p n t A B$ genes including the $p n t A$ ribosome binding site were amplified by polymerase chain reaction (PCR) from chromosomal DNA of $E$. coli MG1655 with the primers pntAB-for (5'-CAG $C T G C A G$ TCA TCA ATA AAA CCG) and pntAB-rev (5'-CGT GAG CTC TTA CAG AGC TTT CAG). After restriction of the 2961-bp PCR product with PstI and SacI, the fragment was ligated into pEKEx2 cut with the same restriction enzymes, transferred into $E$. coli $\mathrm{DH} 5 \alpha$, and plated on LB plates containing $50 \mu \mathrm{g} / \mathrm{ml}$ kanamycin. Plasmids from kanamycin-resistant clones were isolated and analysed by restriction with PstI and SacI. One of the plasmids containing the pntAB fragment was used for transformation of C. glutamicum strains ATCC13032 and DM1730 by electroporation.

Membrane isolation and determination of protein concentration

For isolation of membranes, cells from a $60-\mathrm{ml}$ culture at an $\mathrm{OD}_{600}$ of 8 were harvested by centrifugation for $10 \mathrm{~min}$ at $5,000 \times g$, washed with one culture volume of TE buffer (10 mM Tris-HCl, $1 \mathrm{mM}$ EDTA, $\mathrm{pH}$ 8.0), and centrifuged again. After resuspension in $1 \mathrm{ml} \mathrm{TE}$ buffer containing $40 \mu \mathrm{l}$ of complete protease inhibitor (Roche Diagnostics) and addition of $100 \mu \mathrm{l}$ RNase/DNase I solution $(1 \mathrm{mg} / \mathrm{ml}$ DNase I, $0.25 \mathrm{mg} / \mathrm{ml}$ RNase A in $50 \mathrm{mM} \mathrm{MgCl}_{2}$ ), cells were disrupted by bead beating $[3 \times 30 \mathrm{~s}$ using a Silamat S5 (Vivadent, Erlangen, Germany)]. Intact cells and cell debris were removed by centrifugation for $20 \mathrm{~min}$ at $5,000 \times \mathrm{g}$ and $4^{\circ} \mathrm{C}$. The resulting cell-free extract was subjected to ultracentrifugation for $90 \mathrm{~min}$ at $150,000 \times \mathrm{g}$ and $4^{\circ} \mathrm{C}$. The sedimented membranes were washed twice in $1 \mathrm{ml} 10 \mathrm{mM}$ Tris- $\mathrm{HCl}$ and finally resuspended in $0.5 \mathrm{ml}$ of the same buffer, resulting in a protein concentration of about $0.2 \mathrm{mg} /$ $\mathrm{ml}$. Protein concentrations were determined with the bicin- choninic acid protein assay (Smith et al. 1985) using bovine serum albumin as the standard.

\section{Measurement of transhydrogenase activity}

To measure pyridine nucleotide transhydrogenase activity, 5 and $10 \mu \mathrm{g}$ membrane protein was added to a 1-ml assay mixture (prewarmed to $30^{\circ} \mathrm{C}$ ) containing $50 \mathrm{mM}$ potassium phosphate ( $\mathrm{pH} 7.0), 100 \mathrm{mM} \mathrm{NaCl}, 0.1 \mathrm{mM}$ NADPH, $0.1 \mathrm{mM} 3$-acetylpyridine-NAD ${ }^{+}$and $10 \mathrm{mM} \beta$-mercaptoethanol, and the increase in absorbance at $375 \mathrm{~nm}$ was used to follow reduction of 3-acetylpyridine-NAD ${ }^{+}$by NADPH. The assay was carried out with a Jasco V560 spectrophotometer at $30^{\circ} \mathrm{C}$ using $10-\mathrm{mm}$ light path cuvettes. For calculation of the specific activity (U/mg protein), an extinction coefficient for 3-acetylpyridine-NADH at $375 \mathrm{~nm}$ of $6.1 \mathrm{mM}^{-1} \mathrm{~cm}^{-1}$ (Venning and Jackson 1999) was used. One unit corresponds to the formation of $1 \mu \mathrm{mol} / \mathrm{min}$ 3-acetylpyridine-NADH.

\section{Quantification of sugars and amino acids}

D-Glucose and D-fructose were quantified by high-performance liquid chromatography (HPLC) using a LaChrom LC system (Merck-Hitachi, Darmstadt, Germany) with a Bio-Rad HPX-87C 300×7.8-mm column (Bio-Rad Laboratories $\mathrm{GmbH}$, München, Germany) at $70^{\circ} \mathrm{C}$ using isocratic elution with $\mathrm{H}_{2} \mathrm{O}$ at a flow rate of $0.6 \mathrm{ml} / \mathrm{min}$. Substances were detected with a refraction index detector. Sucrose was quantified enzymatically with a sucrose/Dglucose kit as described by the manufacturer (R-Biopharm, Darmstadt, Germany). Sample concentrations were determined by comparison with external standards.

Quantitative determination of L-lysine and L-glutamate in supernatants was carried out by reversed phase HPLC at $40^{\circ} \mathrm{C}$ after pre-column derivatization with a mixture of $o$ - 
phthaldialdehyde and $\beta$-mercaptoethanol (Pierce Biotechnology, Rockford, USA) according to Lindroth and Mopper (1979) using an Agilent 1100 LC system (Agilent Technologies, Waldbronn, Germany) with an ODS Hypersil $120 \times 4-\mathrm{mm}$ column (CS Chromatographie Service GmbH, Langerwehe, Germany) with $5-\mu \mathrm{m}$ particle size and a guard cartridge $(40 \times 4 \mathrm{~mm})$. L-Ornithine and L-asparagine at final concentrations of $1 \mathrm{mM}$ and $50 \mu \mathrm{M}$, respectively, were used as internal standards in each sample. Substances were eluted with a flow rate of $0.35 \mathrm{ml} \mathrm{min}{ }^{-1}$ within the first minute and $0.6 \mathrm{ml} \mathrm{min}{ }^{-1}$ for the following 15 min with a gradient of $0.1 \mathrm{M}$ sodium acetate $(\mathrm{pH} 7.2)$ as the polar phase and methanol as the non-polar phase. Fluorescence of the amino acid isoindol derivatives was detected at an emission wavelength of $450 \mathrm{~nm}$ after excitation at $230 \mathrm{~nm}$ using a fluorescence detector.

\section{Determination of physiological parameters}

Growth was followed by measuring the $\mathrm{OD}_{600}$ with an Ultrospec 500-pro spectrophotometer (Amersham Biosciences). The biomass concentration was calculated from $\mathrm{OD}_{600}$ values using an experimentally determined correlation factor of $0.25 \mathrm{~g}$ cell dry weight $(\mathrm{cdw}) \mathrm{l}^{-1}$ for $\mathrm{OD}_{600}=1$. The carbon content of cells grown in CGXII glucose medium was previously determined to be $40 \%$ of the cell dry weight (Liebl 2005).

\section{Results}

Effect of pntAB expression in C. glutamicum DM1730 on growth and lysine production with PTS sugars

As the NADPH supply is a critical factor in lysine production by $C$. glutamicum, we tested whether the membrane-bound nicotinamide nucleotide transhydrogenase PntAB from E. coli can be used to improve NADPH provision and, thereby, also lysine production. For this purpose, we expressed the E. coli pntAB genes under the control of an IPTG-inducible tac promoter in the defined lysine-producing strain $C$. glutamicum DM1730 using the plasmid pEKEx2-pntAB. For measuring membrane-associated transhydrogenase activitiy, C. glutamicum DM1730 carrying either the pEKEx2-pntAB plasmid or the expression vector pEKEx2 (negative control) was cultivated in CGXII minimal medium with $4 \%$ glucose in the presence and in the absence of IPTG. The specific transhydrogenase activity, which was measured as the reduction of 3acetylpyridine-NAD ${ }^{+}$by NADPH, was below the detection limit of the assay (approximately $0.01 \mathrm{U} / \mathrm{mg}$ protein) in strain DM1730/pEKEx2 cultivated without or with IPTG and in DM1730/pEKEx2-pntAB grown without IPTG. In contrast, DM1730/pEKEx2-pntAB cultivated in the presence of IPTG showed a transhydrogenase activity of $0.7 \pm 0.1$ $\mu \mathrm{mol} \mathrm{min}{ }^{-1}$ (mg membrane protein $)^{-1}$. This result indicated that the expression of the E. coli pntAB genes in $C$. glutamicum led to the synthesis of an active transhydrogenase.

For analysing the effect of pntAB expression on growth and lysine formation, C. glutamicum DM1730/pEKEx2pntAB and the reference strain DM1730/pEKEx2 were cultivated in CGXII minimal medium containing $50 \mu \mathrm{g} / \mathrm{ml}$ kanamycin, $1 \mathrm{mM}$ IPTG, and as carbon source, $10 \%$ glucose or $10 \%$ fructose or $5 \%$ glucose plus $5 \%$ fructose or $10 \%$ sucrose. In Table 2, carbon source consumption, biomass formation and lysine production, as measured after $72 \mathrm{~h}$, are summarized. The reference strain consumed much more glucose than fructose, glucose plus fructose or sucrose. In the pntAB-expressing strain, glucose consumption was slightly decreased, whereas the consumption of fructose, glucose plus fructose, and sucrose was increased, in particular, that of sucrose about twofold. With respect to biomass synthesis, pntAB expression led to increases between 10 and $30 \%$ on all carbon sources. The lysine concentration was increased in the presence of transhydrogenase on all carbon sources tested, but to a highly varying extent: about $10 \%$ on glucose, $70 \%$ on fructose, $50 \%$ on glucose plus fructose and $300 \%$ on sucrose. The lysine yield (mol-C lysine/mol-C carbon source consumed) was increased on all carbon sources, most strongly on sucrose (Fig. 1a). The biomass yield (mol-C biomass formed/mol-C carbon source consumed) was increased in the case of glucose, unchanged in the case of fructose, and decreased on glucose plus fructose and on sucrose (Fig. 1b).

Effect of pntAB expression in C. glutamicum ATCC13032 on growth and glutamate production with PTS sugars

In contrast to lysine formation, glutamate production requires only 1 mol NADPH per mole glutamate. In $C$. glutamicum, NADPH for the glutamate dehydrogenasecatalyzed reductive amination of 2-oxoglutarate is provided by the isocitrate dehydrogenase reaction in the tricarboxylic acid cycle (Eikmanns et al. 1995). The possibility for NADPH formation by a membrane-bound transhydrogenase should consequently be much less relevant for glutamate formation than for lysine formation. To test this proposal, the $C$. glutamicum wild-type strain ATCC13032 was transformed with pEKEx2-pntAB or the control vector pEKEx 2 and analysed with respect to growth and glutamate formation. The two strains were cultivated for $27 \mathrm{~h}$ in CGXII medium with $50 \mu \mathrm{g} / \mathrm{ml}$ kanamycin, $1 \mathrm{mM}$ IPTG, and either $4 \%(w / v)$ glucose, or $4 \%(w / v)$ fructose, or $2 \%$ $(w / v)$ glucose plus $2 \%(w / v)$ fructose, or $4 \%(w / v)$ sucrose. Glutamate excretion was triggered by adding $300 \mu \mathrm{g} / \mathrm{ml}$ ethambutol to the medium before inoculation (Radmacher 
Table 2 Influence of pntAB expression in the defined lysine-producing strain C. glutamicum DM1730 on biomass and lysine formation from glucose, fructose, glucose plus fructose or sucrose (mean values from two independent cultures measured after $72 \mathrm{~h}$ of cultivation; deviation was below 5\%)

\begin{tabular}{|c|c|c|c|c|c|c|c|c|}
\hline \multirow{2}{*}{$\begin{array}{l}\text { Carbon source } \\
\text { PntAB plasmid }\end{array}$} & \multicolumn{2}{|c|}{$10 \%$ Glucose } & \multicolumn{2}{|c|}{$10 \%$ Fructose } & \multicolumn{2}{|c|}{$5 \%$ Glucose $+5 \%$ fructose } & \multicolumn{2}{|c|}{$10 \%$ Sucrose } \\
\hline & + & - & + & - & + & - & + & - \\
\hline Carbon source consumed (mM) & 474 & 540 & 287 & 236 & $\begin{array}{l}190 \\
125\end{array}$ & $\begin{array}{l}163 \\
106\end{array}$ & 267 & 126 \\
\hline Mol-C carbon source consumed (mM) & 2,844 & 3,240 & 1,722 & 1,416 & 1,890 & 1,614 & 3,204 & 1,512 \\
\hline Cell dry weight $(g / 1)$ & 15.2 & 14.3 & 6.5 & 5.7 & 9.9 & 9.0 & 9.8 & 7.5 \\
\hline $\mathrm{C}$ in biomass $(\mathrm{g} / \mathrm{l})$ & 6.1 & 5.7 & 2.6 & 2.3 & 4.0 & 3.6 & 3.9 & 3.0 \\
\hline Mol-C in biomass $(\mathrm{mM})$ & 508 & 477 & 217 & 190 & 330 & 300 & 327 & 250 \\
\hline Lysine formed (mM) & 87 & 79 & 22 & 13 & 26 & 17 & 69 & 17 \\
\hline Mol-C lysine (mM) & 522 & 474 & 132 & 78 & 156 & 102 & 414 & 102 \\
\hline
\end{tabular}

et al. 2005). In Table 3, carbon source consumption, biomass formation, and glutamate production, as measured after $27 \mathrm{~h}$, are summarized. The biomass formed by strain 13032/pEKEx-pntAB was reduced compared to the reference strain 13032/pEKEx2 on all carbon sources tested by $13-26 \%$. At the same time, the glutamate concentration was also reduced in the presence of transhydrogenase by 4 $36 \%$. Thus, expression of the transhydrogenase genes $p n t A B$ had a negative impact on growth and glutamate formation. As both strains had consumed all of the carbon source, the glutamate yields and the biomass yields were decreased in the pntAB-expressing strain (Table 3 ), indicating that transhydrogenase caused a shift in carbon source usage from biomass and glutamate formation to $\mathrm{CO}_{2}$ or byproduct synthesis.

\section{Discussion}

Hitherto, an increased flux through the oxidative PPP was identified as the almost exclusive way to improve the NADPH supply for lysine biosynthesis by C. glutamicum. In this study, we tested another possibility of NADPH provision based on the activity of the membrane-bound nicotinamide nucleotide transhydrogenase PntAB from $E$. coli. This enzyme uses the proton-motive force to drive the reduction of $\mathrm{NADP}^{+}$to NADPH by oxidation of NADH to $\mathrm{NAD}^{+}$(for a recent review, see Jackson 2003). In $C$. glutamicum, the proton-motive force is generated mainly by the cytochrome $b c_{1}-a a_{3}$ supercomplex (Niebisch and Bott 2003) of the respiratory chain or less efficiently by cytochrome $b d$ oxidase (Bott and Niebisch 2003, 2005). The transhydrogenase activity of $0.7 \mu \mathrm{mol} \mathrm{min}^{-1}$ (mg membrane protein $)^{-1}$ measured in $C$. glutamicum carrying the pEKEx2-pntAB plasmid was in the same range as that determined for Saccharomyces cerevisiae expressing the $E$. coli pntAB genes (Anderlund et al. 1999) and about 40-fold higher than the intrinsic PntAB-catalyzed transhydrogenase activity of E. coli (Sauer et al. 2004).

In the defined lysine-producing strain DM1730, the presence of an active transhydrogenase stimulated the consumption of fructose, glucose plus fructose and sucrose, indicating that an insufficient NADPH supply might be responsible for the restricted utilization of these carbon sources. The most drastic effect was observed on sucrose, whose consumption was doubled by pntAB expression. Sucrose is taken up into the cell as sucrose-6-phosphate by a PEP-dependent phosphotransferase system (ptsS) and
Fig. 1 Influence of pntAB expression in $C$. glutamicum on lysine yield (a) and biomass yield (b) after cultivation for $72 \mathrm{~h}$ on $10 \%(\mathrm{w} / \mathrm{v})$ of glucose, fructose or sucrose or $5 \%(\mathrm{w} / \mathrm{v})$ each of glucose and fructose. White columns, strain DM1730/ pEKEx 2; grey columns, strain DM1730/pEKEx2-pntAB. The data represent mean values and deviation of two independent experiments
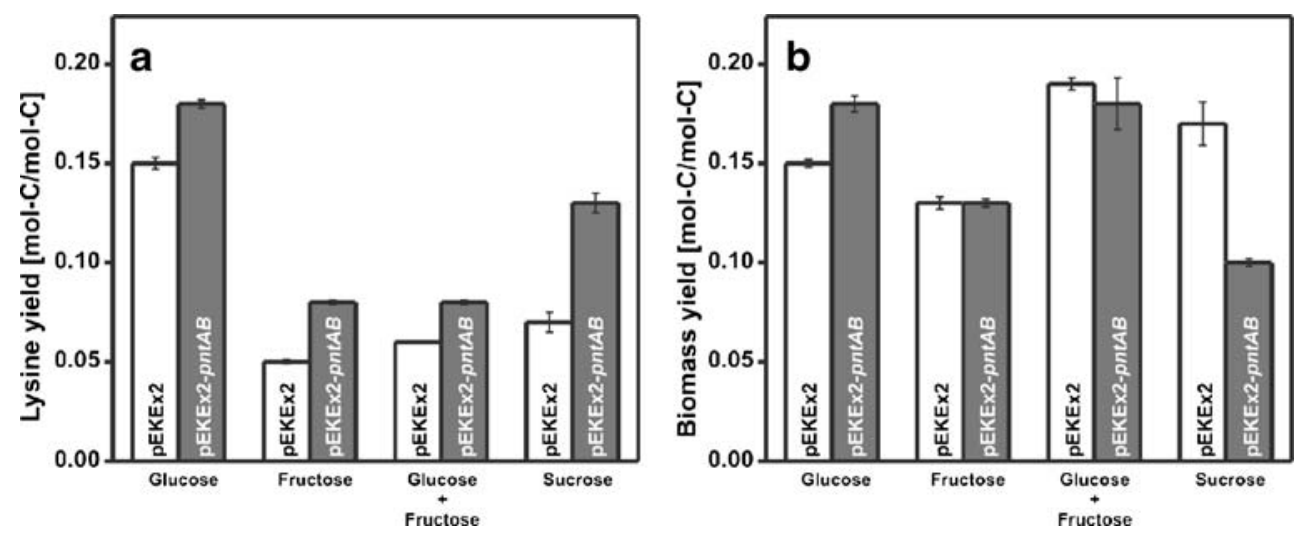
Table 3 Influence of pntAB expression in C. glutamicum ATCC13032 on biomass and ethambutol-induced glutamate formation on glucose, fructose, glucose plus fructose or sucrose (mean values from two independent cultures measured after $27 \mathrm{~h}$ of cultivation; deviation was below $5 \%$ )

\begin{tabular}{|c|c|c|c|c|c|c|c|c|}
\hline \multirow{2}{*}{$\begin{array}{l}\text { Carbon source } \\
\text { PntAB plasmid }\end{array}$} & \multicolumn{2}{|c|}{$4 \%$ Glucose } & \multicolumn{2}{|c|}{$4 \%$ Fructose } & \multicolumn{2}{|c|}{$2 \%$ Glucose $+2 \%$ fructose } & \multicolumn{2}{|c|}{$4 \%$ Sucrose } \\
\hline & + & - & + & - & + & - & + & - \\
\hline Carbon source consumed (mM) & 222 & 222 & 222 & 222 & $\begin{array}{l}111 \\
111\end{array}$ & $\begin{array}{l}111 \\
111\end{array}$ & 117 & 117 \\
\hline Mol-C carbon source consumed (mM) & 1,332 & 1,332 & 1,332 & 1,332 & 1,332 & 1,332 & 1,404 & 1,404 \\
\hline Cell dry weight (g/l) & 8.85 & 103 & 6.25 & 7.05 & 7.9 & 9.15 & 7.53 & 10.15 \\
\hline $\mathrm{C}$ in biomass $(\mathrm{g} / \mathrm{l})$ & 3.54 & 4.12 & 2.5 & 2.82 & 3.16 & 3.66 & 3.01 & 4.06 \\
\hline Mol-C in biomass (mM) & 295 & 343 & 208 & 235 & 263 & 305 & 251 & 338 \\
\hline Biomass yield (mol-C/mol-C) & 0.22 & 0.26 & 0.16 & 0.18 & 0.20 & 0.23 & 0.18 & 0.24 \\
\hline Glutamate formed (mM) & 44 & 53 & 51 & 53 & 41 & 52 & 36 & 56 \\
\hline Mol-C glutamate (mM) & 220 & 265 & 255 & 265 & 205 & 260 & 180 & 280 \\
\hline Glutamate yield (mol-C/mol-C) & 0.17 & 0.20 & 0.19 & 0.20 & 0.15 & 0.20 & 0.13 & 0.20 \\
\hline
\end{tabular}

subsequently hydrolyzed to glucose-6-phosphate and fructose by sucrose-6-phosphate hydrolase (Moon et al. 2005). As $C$. glutamicum lacks a fructokinase enzyme, the free fructose is transported out of the cell and subsequently taken up as fructose-1-phosphate by the fructose-PTS $(p t s F)$ and, to a minor proportion, as fructose-6-phosphate by the glucose-PTS (ptsG; Dominguez and Lindley 1996; Dominguez et al. 1998; Moon et al. 2005). As glucose-6phosphate generated from sucrose can be directly metabolized in the oxidative pentose phosphate pathway, it is unclear why there should be a deficiency in NADPH supply during growth on sucrose that is relieved by transhydrogenase. Free fructose or fructose-1-phosphate can possibly act as an allosteric effector that inhibits the operation of the oxidative pentose phosphate pathway.

As shown in Table 2, the presence of transhydrogenase stimulated lysine formation on all carbon sources tested. The smallest increase was observed on glucose $(\sim 10 \%)$, probably due to the fact that the NADPH supply is almost sufficient due to a high carbon flux through the oxidative PPP. Mid or large increases in lysine concentration were observed on fructose $(\sim 70 \%)$, glucose plus fructose $(\sim 50 \%)$, and sucrose $(\sim 300 \%)$, suggesting that on these carbon sources the NADPH supply significantly limits lysine synthesis. However, the absolute lysine concentration (and also lysine and biomass yield) was still higher on glucose than on fructose or sucrose. Whereas the lysine yields were increased on all carbon sources in the presence of transhydrogenase, the biomass yield was increased on glucose, unchanged on fructose, and decreased on glucose plus fructose and on sucrose. This indicates that the increased lysine yield on sucrose and glucose plus fructose is obtained at the expense of a reduced biomass yield, whereas the increased lysine yield on glucose and on fructose is achieved at the expense of reduced $\mathrm{CO}_{2}$ (or byproduct) formation. Reduced $\mathrm{CO}_{2}$ formation might be caused by a reduced flux through the oxidative PPP due to the inhibition of glucose-6-phosphate dehydrogenase and 6phosphogluconate dehydrogenase by high NADPH concentrations (Moritz et al. 2000).

In contrast to the positive effects of pntAB expression in the lysine-producing strain DM1730, both growth and glutamate formation were negatively influenced by pntAB expression in the wild-type strain ATCC13032 cultivated in the presence of ethambutol. The reason for this inhibitory effect is not yet clear and requires further experimentation. In summary, our data have shown that the proton-coupled transhydrogenase PntAB of E. coli is a valuable metabolic engineering tool for increasing lysine synthesis by $C$. glutamicum, in particular, on carbon sources containing fructose and sucrose.

Acknowledgement Financial support by R\&D Feed Additives of Degussa AG is gratefully acknowledged. C. glutamicum strain DM1730 was a kind gift of Dr. Brigitte Bathe, Degussa AG.

\section{References}

Abe S, Takayama K, Kinoshita S (1967) Taxonomical studies on glutamic acid producing bacteria. J Gen Appl Microbiol 13:279-301

Anderlund M, Nissen TL, Nielsen J, Villadsen J, Rydstrom J, HahnHagerdal B, Kielland-Brandt MC (1999) Expression of the Escherichia coli pntA and pntB genes, encoding nicotinamide nucleotide transhydrogenase, in Saccharomyces cerevisiae and its effect on product formation during anaerobic glucose fermentation. Appl Environ Microbiol 65:2333-2340

Ausubel F, Brent R, Kingston RE, Moore DD, Seidmann JG, Smith JA, Struhl K (1992) Preparation of genomic DNA. In: Ausubel F (ed) Short protocols in molecular biology. Wiley, New York, pp A1-A60

Bott M, Niebisch A (2003) The respiratory chain of Corynebacterium glutamicum. J Biotechnol 104:129-153

Bott M, Niebisch A (2005) Respiratory energy metabolism. In: Eggeling L, Bott M (eds) Handbook of Corynebacterium glutamicum. CRC, Boca Raton, pp 307-334 
Clarke DM, Bragg PD (1985) Cloning and expression of the transhydrogenase gene of Escherichia coli. J Bacteriol 162:367-373

Dominguez H, Lindley ND (1996) Complete sucrose metabolism requires fructose phosphotransferase activity in Corynebacterium glutamicum to ensure phosphorylation of liberated fructose. Appl Environ Microbiol 62:3878-3880

Dominguez H, Rollin C, Guyonvarch A, Guerquin-Kern JL, CocaignBousquet M, Lindley ND (1998) Carbon-flux distribution in the central metabolic pathways of Corynebacterium glutamicum during growth on fructose. Eur J Biochem 254:96-102

Eggeling L (1994) Biology of L-lysine overproduction by Corynebacterium glutamicum. Amino Acids 6:261-272

Eggeling L, Sahm H (1999) L-glutamate and L-lysine: traditional products with impetuous developments. Appl Microbiol Biotechnol 52:146-153

Eikmanns BJ, Kleinertz E, Liebl W, Sahm H (1991) A family of Corynebacterium glutamicum/Escherichia coli shuttle vectors for cloning, controlled gene expression and promoter probing. Gene 102:93-98

Eikmanns BJ, Rittmann D, Sahm H (1995) Cloning, sequence analysis, expression, and inactivation of the Corynebacterium glutamicum icd gene encoding isocitrate dehydrogenase and biochemical characterization of the enzyme. J Bacteriol 177:774-782

Georgi T, Rittmann D, Wendisch VF (2005) Lysine and glutamate production by Corynebacterium glutamicum on glucose, fructose and sucrose: roles of malic enzyme and fructose-1,6-bisphosphatase. Metab Eng 7:291-301

Gourdon P, Baucher MF, Lindley ND, Guyonvarch A (2000) Cloning of the malic enzyme gene from Corynebacterium glutamicum and role of the enzyme in lactate metabolism. Appl Environ Microbiol 66:2981-2987

Hanahan D (1985) Techniques for transformation of E. coli. In: Glover DM (ed) DNA-cloning: a practical approach, IRL, Oxford, pp. 109-135

Hermann $T$ (2003) Industrial production of amino acids by coryneform bacteria. J Biotechnol 104:155-172

Jackson JB (2003) Proton translocation by transhydrogenase. FEBS Lett 545: $18-24$

Kelle R, Hermann T, Bathe B (2005) L-Lysine production. In: Eggeling L, Bott M (eds) Handbook of Corynebacterium glutamicum. CRC, Boca Raton, pp 467-490

Keilhauer C, Eggeling L, Sahm H (1993) Isoleucine synthesis in Corynebacterium glutamicum: molecular analysis of the ilvB$i l v N-i l v C$ operon. J Bacteriol 17:5595-5603

Kiefer P, Heinzle E, Zelder O, Wittmann C (2004) Comparative metabolic flux analysis of lysine-producing Corynebacterium glutamicum cultured on glucose or fructose. Appl Environ Microbiol 70:229-239

Kimura E (2005) L-Glutamate production. In: Eggeling L, Bott M (eds) Handbook of Corynebacterium glutamicum. CRC, Boca Raton, pp 441-465

Kotrba P, Inui M, Yukawa H (2001) The ptsI gene encoding enzyme I of the phosphotransferase system of Corynebacterium glutamicum. Biochem Biophys Res Commun 289:1307-1313

Liebl W (2005) Corynebacterium taxonomy. In: Eggeling L, Bott M (eds) Handbook of Corynebacterium glutamicum. CRC, Boca Raton, pp 9-34

Lindroth P, Mopper K (1979) High performance liquid chromatographic determination of subpicomole amounts of amino acids by pre-column fluorescence derivatization with $o$-phthaldialdehyde. Anal Chem 51:1667-1674

Marx A, de Graaf AA, Wiechert W, Eggeling L, Sahm H (1996) Determination of the fluxes in the central metabolism of Corynebacterium glutamicum by nuclear magnetic resonance spectroscopy combined with metabolite balancing. Biotechnol Bioeng 49:111-129
Marx A, Striegel K, de Graaf AA, Sahm H, Eggeling L (1997) Response of the central metabolism of Coyrnebacterium glutamicum to different flux burdens. Biotechnol Bioeng 56:168-180

Marx A, Eikmanns BJ, Sahm H, de Graaf AA, Eggeling L (1999) Response of the central metabolism in Corynebacterium glutamicum to the use of an NADH-dependent glutamate dehydrogenase. Metab Eng 1:35-48

Marx A, Hans S, Mockel B, Bathe B, de Graaf AA (2003) Metabolic phenotype of phosphoglucose isomerase mutants of Corynebacterium glutamicum. J Biotechnol 104:185-197

Moon MW, Kim HJ, Oh TK, Shin CS, Lee JS, Kim SJ, Lee JK (2005) Analyses of enzyme II gene mutants for sugar transport and heterologous expression of fructokinase gene in Corynebacterium glutamicum ATCC 13032. FEMS Microbiol Lett 244:259-266

Moritz B, Striegel K, de Graaf AA, Sahm H (2000) Kinetic properties of the glucose-6-phosphate and 6-phosphogluconate dehydrogenases from Corynebacterium glutamicum and their application for predicting pentose phosphate pathway flux in vivo. Eur $\mathrm{J}$ Biochem 267:3442-3452

Niebisch A, Bott M (2003) Purification of a cytochrome $b c_{1}-a a_{3}$ supercomplex with quinol oxidase activity from Corynebacterium glutamicum. Identification of a fourth subunit of cytochrome $a a_{3}$ oxidase and mutational analysis of diheme cytochrome $c_{1}$. J Biol Chem 278:4339-4346

Ohnishi J, Mitsuhashi S, Hayashi M, Ando S, Yokoi H, Ochiai K, Ikeda M (2002) A novel methodology employing Corynebacterium glutamicum genome information to generate a new L-lysineproducing mutant. Appl Microbiol Biotechnol 58:217-223

Parche S, Burkovski A, Sprenger GA, Weil B, Kramer R, Titgemeyer F (2001) Corynebacterium glutamicum: a dissection of the PTS. J Mol Microbiol Biotechnol 3:423-428

Pfefferle W, Möckel B, Bathe B, Marx A (2003) Biotechnological manufacture of lysine. Adv Biochem Eng Biotechnol 79:59-112

Pons A, Dussap CG, Pequinot C, Gros JB (1996) Metabolic flux distribution in Corynebacterium melassecola ATCC 17965 for various carbon sources. Biotechnol Bioeng 51:77-189

Radmacher E, Stansen KC, Besra GS, Alderwick LJ, Maughan WN, Hollweg G, Sahm H, Wendisch VF, Eggeling L (2005) Ethambutol, a cell wall inhibitor of Mycobacterium tuberculosis, elicits L-glutamate efflux of Corynebacterium glutamicum. Microbiology 151:1359-1368

Rittmann D, Schaffer S, Wendisch VF, Sahm H (2003) Fructose-1,6bisphosphatase from Corynebacterium glutamicum: expression and deletion of the $f b p$ gene and biochemical characterization of the enzyme. Arch Microbiol 180:285-292

Sahm H, Eggeling L, de Graaf AA (2000) Pathway analysis and metabolic engineering in Corynebacterium glutamicum. Biol Chem 381:899-910

Sauer U, Canonaco F, Heri S, Perrenoud A, Fischer E (2004) The soluble and membrane-bound transhydrogenases UdhA and PntAB have divergent functions in NADPH metabolism of Escherichia coli. J Biol Chem 279:6613-6619

Smith PK, Krohn RI, Hermanson GT, Mallia AK, Gartner FH, Provenzano MD, Fujimoto EK, Goeke NM, Olson BJ, Klenk DC (1985) Measurement of protein using bicinchoninic acid. Anal Biochem 150:76-85

van der Rest ME, Lange C, Molenaar D (1999) A heat shock following electroporation induces highly efficient transformation of Corynebacterium glutamicum with xenogenic plasmid DNA. Appl Microbiol Biotechnol 52:541-545

Venning JD, Jackson JB (1999) A shift in the equilibrium constant at the catalytic site of proton-translocating transhydrogenase: significance for a 'binding-change' mechanism. Biochem $\mathrm{J}$ 341:329-337 